\title{
Chemotaxins C5a and fMLP induce release of calprotectin (leucocyte L1 protein) from polymorphonuclear cells in vitro
}

\author{
G Hetland, G J Talgö, M K Fagerhol
}

\begin{abstract}
Aims-To determine whether the chemotaxins C5a and formyl peptide (fMLP) can stimulate the release of calprotectin, the major leucocyte protein of polymorphonuclear neutrophils (PMN).

Methods-A dose response curve for the uptake of ${ }^{125} I$ labelled rC5a and fMLP in PMN was determined by radioimmunoassay. The unlabelled chemotaxins were then incubated with PMN and the concentration of calprotectin in PMN lysates and supernatants was measured by an enzyme immunoassay.

Results-Both rC5a and fMLP induced release of calprotectin from $P M N$ in a dose dependent manner as determined by a reduction in intracellular calprotectin concentration. A minimum of $\sim 10 \%$ of total PMN calprotectin was retained at concentrations of 10-100 $\mathrm{nM}$ of $\mathrm{rC5a}$ and 0.1-10.0 nM of fMLP. Antibodies to C5a reduced the $\mathrm{rC5} 5$ mediated release of calprotectin, and the fMLP antagonist $\mathrm{N}-\mathrm{t}$ Boc-MLP inhibited the fMLP induced calprotectin release. Because receptors for rC5a (CD88) and fMLP are G protein coupled and thought to be pertussis toxin sensitive, PMN were incubated with this toxin before the experiments. The toxin was found to reduce uptake of $\mathrm{rC5a}$ by the cells and to inhibit rC5a and fMLP mediated calprotectin release.

Conclusions-rC5a and fMLP mediate release of calprotectin from $P M N$ in vitro. This effect might be important during human infections in vivo.

( 7 Clin Pathol: Mol Pathol 1998;51:143-148)
\end{abstract}

Institute of

Immunology and

Rheumatology, The

National Hospital,

Oslo, Norway

G Hetland

Blood Bank and

Department of

Immunology, Ullevål

Hospital, Oslo, Norway

G J Talgö

M K Fagerhol

Correspondence to: Dr Hetland, Section of Environmental Immunology, Department of

Environmental Medicine, Institute of Public Health, PO Box 4404 Torshov, N-0403 Oslo, Norway.

Accepted for publication 5 February 1998
$\mathrm{C} 5 \mathrm{a}$ is a potent proinflammatory mediator generated during complement activation. It is formed when $\mathrm{C} 5$ is cleaved, to give $\mathrm{C} 5 \mathrm{a}$ and $\mathrm{C} 5 \mathrm{~b}$. C $5 \mathrm{~b}$ binds to $\mathrm{C} 6-\mathrm{C} 9$ to form the terminal complement complex, which is either inserted as a cytolytic complex into membranes or solubilised by vitronectin/S protein and clusterin (SC5b-9). C5a exerts its anaphylatoxic activities by binding to a specific $\mathrm{C} 5 \mathrm{a}$ receptor (CD88) on PMN, ${ }^{10}$ monocytes, and nonmyeloid cells. ${ }^{11}$ Recently, the $\mathrm{C} 5$ a receptor has been cloned and characterised. ${ }^{12}$ The bacterial chemotaxin formyl-methionine-leucinephenylalanine (fMLP) binds to a specific formyl peptide receptor on myeloid cells and dendritic cells. ${ }^{1314}$ Both the $\mathrm{C} 5$ a receptor and the fMLP receptor are coupled to a pertussis toxin sensitive G protein. ${ }^{15}$ Stimulation of PMN with these ligands triggers a range of biological activities including chemotaxis, superoxide formation, enzyme release, and aggregation. ${ }^{16-19}$

Previously, we found that the plasma concentration of calprotectin increased after plasma apheresis in patients with Waldenström's syndrome, ${ }^{20}$ and suspected that this was related to the increase in complement activation products seen in one of these patients. ${ }^{21}$ Recently, Garred et al showed that the release of calprotectin coincided with activation of complement during major surgery. ${ }^{22}$ The purpose of our study was to examine whether C5a and the bacterial product fMLP, which has similar biological effects, induce secretion of calprotectin from PMN in vitro.

\section{Materials and methods}

PREPARATION OF PMN

The source of PMN was fresh buffy coats $(\sim 50 \mathrm{ml})$ from blood units used to make platelet concentrates at the hospital's blood bank. A volume of $2.5 \mathrm{ml}$ of $20 \mathrm{~g} / \mathrm{EDTAK}_{2}, \mathrm{pH} 7.0$, was added to each buffy coat. Next, one volume of buffy coat/EDTAK ${ }_{2}$ was mixed with four volumes of cold $\left(4^{\circ} \mathrm{C}\right)$ isotonic $\mathrm{NH}_{4} \mathrm{Cl}$ containing $10 \% \mathrm{NaHCO}_{3} \mathrm{wt} / \mathrm{wt}$, and stored at $4^{\circ} \mathrm{C}$ for 10 minutes before centrifugation at this temperature at $160 \times g$ for 10 minutes. The haemolysate was removed and the pellet was resuspended, washed once in isotonic $\mathrm{NaCl}$ containing $1 \mathrm{~g} / 1 \mathrm{EDTAK}_{2}$, and centrifuged for 15 minutes at $800 \times g$ through a layer of LymphoprepR (Nycomed, Oslo, Norway). ${ }^{23}$ The PMN pellet was washed by centrifugation in a veronal (Diemal) buffer containing $1 \mathrm{~g} / 1$ EDTAK $_{2}$ and usually resuspended to $10 \times 10^{6}$ $\mathrm{PMN} / \mathrm{ml}$ in the same buffer. Typically, the cell preparations consisted of $>96 \%$ PMN and contained $>98 \%$ live cells (trypan blue exclusion) after a further incubation of one hour. All the buffers were autoclaved and sterile, and 


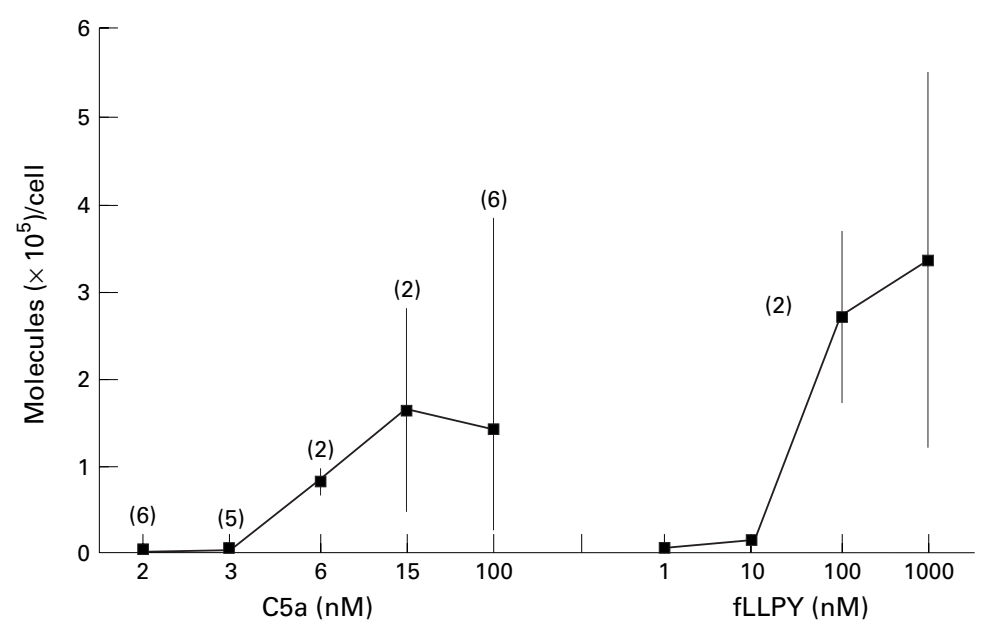

Figure 1 Dose response curve for the uptake of ${ }^{125}$ I labelled $r C 5$ a and $f^{N} L L P Y$ by human $P M N$. Data reported as molecules bound and internalised/cell after 15 minutes incubation at $37^{\circ} \mathrm{C}$. The cells $\left(5 \times 10^{5}\right)$ were incubated in $100 \mu$ l of buffer. Values given are medians (closed squares) and ranges (vertical lines) of two to six experiments performed in triplicate.

endotoxin free tubes and plastic were used to prevent endotoxin contamination.

RADIOACTIVE LABELLING OF RECOMBINANT C5a AND $f^{N} L L P Y$

Human recombinant (r) C5a (C 5788; Sigma Chemical Co, St Louis, Missouri, USA) or $\mathrm{N}$-formyl-N-leucine-leucine-phenylalaninetyrosine (f ${ }^{\mathrm{N}}$ LLPY) (F 2134; Sigma) were labelled with ${ }^{125} \mathrm{I}\left(\mathrm{Na}^{125} \mathrm{I}\right.$; Amersham Corp, Arlington Heights, Illinois, USA) using a solid phase lactoperoxidase glucose oxidase (Enzymo-bead; Pierce, Rockford, Illinois, USA) as described previously. ${ }^{24}$ Formyl${ }^{\mathrm{N}}$ LLPY was used instead of fMLP to enable the peptide to be labelled with iodine. The specific activities of the $\mathrm{rC} 5 \mathrm{a}$ and $\mathrm{f}^{\mathrm{N}} \mathrm{LLPY}$ preparations were between 10 and $50 \mu \mathrm{Ci} / \mu \mathrm{g}$. rC5a and iodine labelled C5a or $\mathrm{f}^{\mathrm{N}}$ LLPY exhibit biological activities similar to serum derived C5a $\left(\right.$ Sigma) ${ }^{24}$ and fMLP (TE Hugli 1991, personal communication), respectively.

ANALYSIS OF CALPROTECTIN

The calprotectin (L1) concentrations in PMN supernatants were analysed by enzyme immunoassay (EIA).$^{25}$ Briefly, the wells (Nunc Immuno Plate; Nunc, Copenhagen, Denmark) were coated with polyclonal rabbit anti-L1 IgG and purified L1 was used as the standard. The binding of PMN L1 was detected by polyclonal alkaline phosphatase conjugated, affinity purified rabbit anti-L1. The specificity of anti-L1 was determined by double immunodiffusion against L1 purified from leucocytes, ${ }^{2}$ by reactivity of anti-L1 in EIA, and by a dot blot against the human plasma gel filtration fraction of $36 \mathrm{kDa}$ corresponding to the molecular mass of calprotectin. ${ }^{26}$ This polyclonal antibody reacts with three different epitopes on each of the two types of polypeptide chains of calprotectin as visualised by epitope mapping using synthetic peptides ( $\mathrm{T}$ Hansen and MK Fagerhol 1996, unpublished data). The coefficient of variation of this method is $\sim 5 \%$ within assays and $\sim 13 \%$ between assays. The specificity of this EIA has also been examined by comparison with an EIA using a mono- clonal anticalprotectin (MAC 387 clone; DAKO, Glostrup, Denmark $)^{27}$ and the two methods were found to be highly positively correlated (MK Fagerhol et al, unpublished data). The normal plasma values of L1 (median $\pm 2 \mathrm{SD}$ ) are $80-880 \mu \mathrm{g} / \mathrm{l}$ (median, 440) for women and 150-910 $\mu \mathrm{g} / \mathrm{l}$ (median, 530) for men. Supernatants and lysates of peptide stimulated PMN were also subjected to sodium dodecyl sulphate polyacrylamide gel electrophoresis (SDS-PAGE) for examination of calprotectin.

DETERMINATION OF PMN UPTAKE OF PEPTIDES AND SECRETION OF CALPROTECTIN Cellular uptake of labelled $\mathrm{rC5} 5$ or $\mathrm{f}^{\mathrm{N}} \mathrm{LLPY}$ was investigated by incubating the peptides for 15 minutes at $37^{\circ} \mathrm{C}$ with $5 \times 10^{5} \mathrm{PMN}$ in $100 \mu \mathrm{l}$ of buffer. The cells were then sedimented, washed, and lysed. Lysis was performed at $0^{\circ} \mathrm{C}$ by sonication for one minute in $100 \mu \mathrm{l}$ of a lysis buffer containing $50 \mathrm{mM}$ HEPES, $10 \mathrm{nM}$ EDTA, $2 \mathrm{mM}$ phenylmethyl sulphonylfluoride (PMSF), 0.1 M iodoacetamide, and $15 \mu \mathrm{g}$ soybean trypsin inhibitor. Radioactivity in the lysis mixture was recorded in a Cobra Autogammacounter (Packard Instruments, Downers Grove, Illinois, USA). The total uptake (binding and internalisation) of labelled rC5a and $\mathrm{P}^{\mathrm{N}} \mathrm{LLPY}$ by the PMN is reported as molecules/cell and the numbers are calculated based on the counts/minute (cpm) values and specific activities of labelled chemotaxins.

To examine whether uptake of C5a could be inhibited by blocking the $G$ protein coupled pathway, PMN, either pretreated or not pretreated with $1 \mu \mathrm{g} / \mathrm{ml}$ of pertussis toxin (Sigma) for 30 minutes at room temperature, were incubated as above, but with unlabelled rC5a. Measurement of C5a in cell lysates was performed in a sandwich EIA based on monoclonal antibodies to a neoepitope on $\mathrm{C} 5 \mathrm{a} / \mathrm{C} 5 \mathrm{a}$ desArg, which is concealed in native $\mathrm{C} 5 \mathrm{a}$ but exposed in the activated fragment. ${ }^{28} 29$

For examination of PMN calprotectin release, rC5a (1-100 nM) and fMLP (0.1$100.0 \mathrm{nM}$ ) (F 3506; Sigma) were incubated with $1-5 \times 10^{6} \mathrm{PMN}$ in $1 \mathrm{ml}$ conical Nunc cryotubes (Nunc) containing veronal buffer with $\mathrm{EDTAK}_{2}$ at $37^{\circ} \mathrm{C}$ in a volume of $100 \mu \mathrm{l}$. The PMN were incubated for 20 minutes to ensure that the plateau for chemotaxin uptake after 15 minutes was reached. Controls were cells incubated with buffer alone, or cells pretreated either with $1 \mu \mathrm{g} / \mathrm{ml}$ of pertussis toxin (P 9452; Sigma), $10 \mathrm{nM}$ of the fMLP antagonist N-t-Boc-MLP (B 0511; Sigma), ${ }^{30}$ or with $10 \mathrm{mg} / \mathrm{ml}$ of human $\gamma$ globulin for 30 minutes at room temperature to block $\mathrm{Fc} \gamma$ receptors before addition of polyclonal antibodies to $\mathrm{C} 5 \mathrm{a}$ $(12.5 \% \mathrm{vol} / \mathrm{vol}$ from Amersham's $\mathrm{C} 5 \mathrm{a} / \mathrm{C} 5 \mathrm{a}$ desArg radioimmunoassay kit) together with C5a. The cells were pelleted and the supernatant removed and stored at $-20^{\circ} \mathrm{C}$ until the concentration of calprotectin was measured. Results from inhibition experiments performed with different concentrations of C5a or fMLP are presented together. The pellets were lysed and frozen immediately. The concentration of 


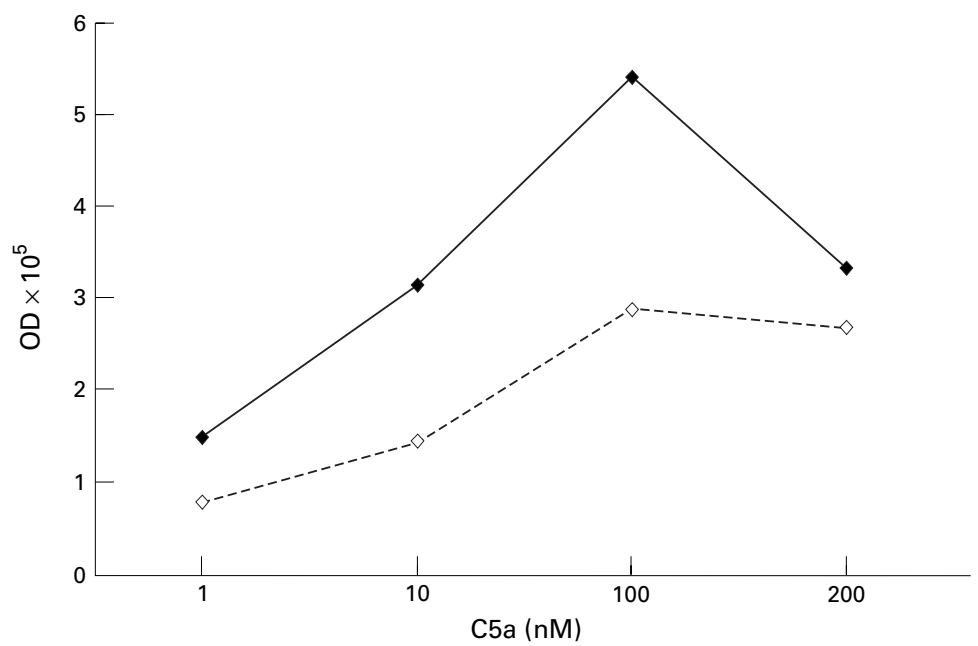

Figure 2 Dose response curve for the uptake of unlabelled rC5 a by PMN that were pre-incubated (dotted line, open symbols) or not pre-incubated (solid line, closed symbols) with pertussis toxin for 30 minutes at room temperature. Data points are the means of two experiments carried out in triplicate. OD, optical density.

calprotectin in PMN lysates or supernatants was measured as $\mu \mathrm{g} / \mathrm{l}$ and reported as a percentage of the measured total calprotectin content in lysates plus supernatants of unstimulated PMN (mean and range values, 2.2 and 1.3-3.6 pg/cell, respectively, which are similar to values published previously).

CONTROLS

To exclude the possibility that endotoxin was responsible for the observed release of calprotectin from PMN, random samples of both the buffers, cell lysates, and supernatants were examined for endotoxin content using a limulus amoebocyte lysate ${ }^{31}$ EIA kit (Chromogenix, Mölndal, Sweden). In some experiments, polymyxin B (P 1004; Sigma), which inactivates endotoxin, ${ }^{32}$ was also added to the cell preparations, but no reduction in background secretion of calprotectin was seen. In other experiments, equal volumes $(5 \mathrm{ml})$ of

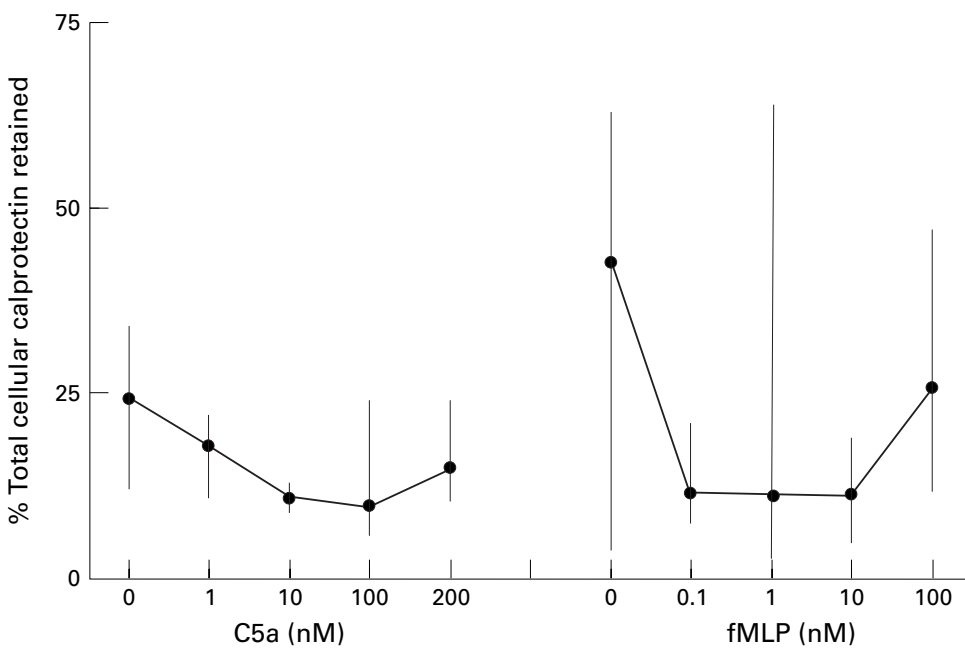

Figure 3 Dose response curve for the release of calprotectin from PMN stimulated with rC5a or $F M L P$, as determined by the remaining intracellular calprotectin concentration. PMN $\left(1-5 \times 10^{6}\right)$ were incubated for 20 minutes at $37^{\circ} \mathrm{C}$ with or without $r C 5$ a or fMLP in $100 \mu$ of buffer, the cells pelleted, and the content of calprotectin in the lysates determined. Values given are medians (closed circles) and 25-75 percentiles (verticle lines) of six experiments (performed in duplicate) and reported as a percentage of the total content of calprotectin in supernatants and lysates of unstimulated cells. untreated buffy coats were either enriched or not enriched with PMN isolated from $5 \mathrm{ml}$ of the same buffy coats, and incubated at $37^{\circ} \mathrm{C}$ and $4^{\circ} \mathrm{C}$ for one, four, or 24 hours and the concentration of calprotectin measured in the plasma supernatants. PMN were also incubated with $10 \mathrm{mM} \mathrm{Ca}{ }^{2+}$, for possible reduction of background by stabilisation of the cells, or with $30 \mathrm{mM}$ PMSF, to reduce proteolysis of calprotectin, but no effects were seen (data not shown).

\section{STATISTICS}

The significance of the results was examined by the non-parametric Wilcoxon signed rank or one sample test. Values are given as medians, ranges, or 25-75 percentiles. The graphic software and statistical analysis program used was GB-STAT (Dynamics Microsyst, Silver Spring, Maryland, USA) and $p$ values $<0.05$ were considered significant.

\section{Results}

UPTAKE OF LABELLED rC5a AND $\mathrm{f}^{\mathrm{N}}$ LLPY IN PMN Figure 1 shows the dose response curve for the uptake (binding and internalisation) of labelled rC5a and $\mathrm{f}^{\mathrm{N}} \mathrm{LLPY}$ by PMN. A plateau was reached at $\sim 1.5 \times 10^{5}$ and $3 \times 10^{5}$ molecules taken up by each cell at rC5a and f $^{\mathrm{N}}$ LLPY concentrations above $10 \mathrm{nM}$ and $100 \mathrm{nM}$, respectively (fig 1). The uptake of $\mathrm{rC} \mathrm{a}^{24}$ and $\mathrm{f}^{\mathrm{N}} \mathrm{LLPY}$ (data not shown) by PMN reaches a plateau after 15 minutes of incubation, the incubation time used here. Uptake of unlabelled $\mathrm{rC} 5 \mathrm{a}$ by PMN pretreated or not pretreated with pertussis toxin $(1 \mu \mathrm{g} / \mathrm{ml})$ was assessed by a C $5 \mathrm{a} / \mathrm{C} 5 \mathrm{a}$ desArg EIA. Uptake was dose dependent and was reduced by pertussis toxin $(p=0.0357$; Wilcoxon signed rank test of all data points) (fig 2).

EFFECT OF rC5a AND FMLF STIMULATION ON SECRETION OF CALPROTECTIN BY PMN

The concentration of calprotectin in lysates and supernatants of PMN incubated with 0-200 nM of rC5a for 20 minutes was examined. rC5a had a dose dependent bimodal stimulatory effect on the release of calprotectin from PMN, as determined by reduction in intracellular calprotectin (fig 3). A minimum of $10 \%$ of total PMN calprotectin was retained at an $\mathrm{rC} 5 \mathrm{a}$ concentration of $100 \mathrm{nM}$, which was significantly lower than the amount retained by the control (no rC5a) ( $<<0.0425$; Wilcoxon signed rank test). PMN stimulated with 0-100 nM fMLP also released calprotectin in a dose dependent bimodal manner (fig 3). Similar minimal values $(11-12 \%)$ of total PMN calprotectin to those observed with C5a stimulation were retained at the three middle fMLP concentrations $(p<0.0431$ compared with control), suggesting that all cell associated calprotectin is released. Thus, C5a and fLMP induced a reduction in the total PMN calprotectin concentration of $\sim 60 \%$ and $70 \%$, respectively, compared with unstimulated control cells.

When calprotectin was measured in PMN supernatents, little or no dose response was seen in rC5a or fMLP stimulated cells PMN 


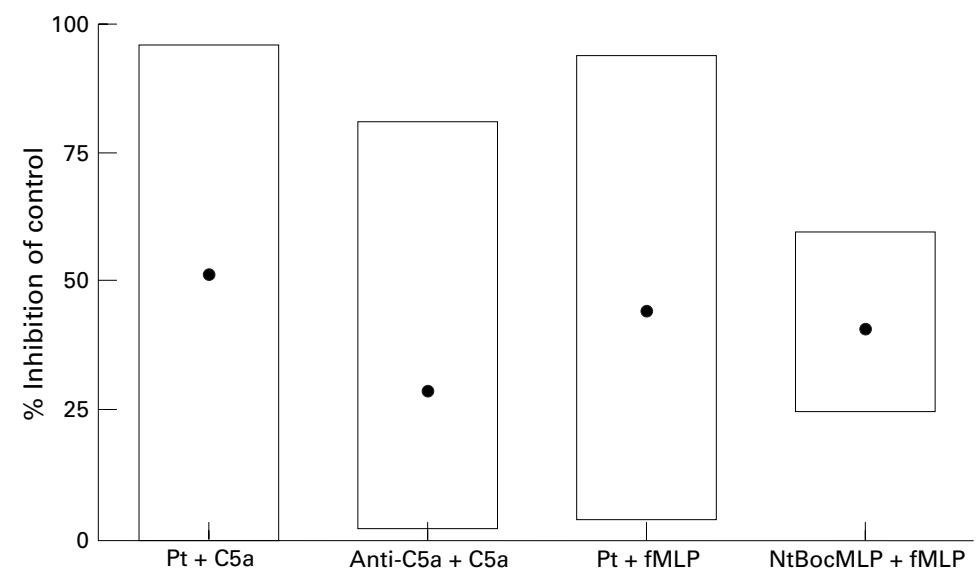

Figure 4 Inhibition of $r C 5$ a or $F M L P$ induced secretion of calprotectin from PMN by treatment of the cells with pertussis toxin (Pt) $(n=12)$, polyclonal anti-C5a antibodies $(n=8)$ or $N-t-B o c-M L P(n=8)$. PMN were incubated with or without the inhibitors for 30 minutes at room temperature, except for anti-C5a, which was added together with $C 5 a$, and then treated as in fig 3. Experiments were performed in duplicate with 1-200 nM of C5a or 0.1-100.0 nM of fMLP. Reduction is calculated as percentage inhibition of the calprotectin concentration measured in lysates of stimulated control cells without inhibitors. Values are given as medians (closed circles) and 25-75 percentiles (boxes).

(data not shown). This is because such stimulation also mediates the release of proteolytic enzymes that digest calprotectin.

REDUCTION OF rC5a AND FMLP MEDIATED RETENTION OF CALPROTECTIN BY TREATMENT OF PMN WITH PERTUSSIS TOXIN, ANTIBODIES, OR ANTAGONIST

To investigate whether the chemotaxin induced PMN secretion of calprotectin is medited by a $G$ protein coupled mechanism, PMN were incubated with pertussis toxin before addition of $\mathrm{rC5a}(1-200 \mathrm{nM})$ or fMLP $(0.1-$ $100.0 \mathrm{nM})$. Figure 4 shows that the secretion of calprotectin from PMN mediated by C5a or fMLP was inhibited significantly; inhibition was $\sim 50 \% \quad(\mathrm{p}=0.0329) \quad$ and $\quad \sim 45 \%$ ( $p=0.0047$; Wilcoxon one sample test of all data points), respectively. When rC5a was added after pre-incubation of PMN with polyclonal anti-C5a, there was a small (30\%), but significant reduction ( $\mathrm{p}=0.0357$; Wilcoxon one-sample test of all data points) in the release of calprotectin.

In experiments with fMLP stimulation, pretreatment of cells with the fMLP antagonist N-t-Boc-MLP reduced the calprotectin secretion by $\sim 40 \% \quad(\mathrm{p}=0.0437$; Wilcoxon one sample test) (fig 4).

DETERMINATION OF CAUSE OF BACKGROUND RELEASE OF CALPROTECTIN

Buffy coat samples were incubated at different temperatures and intervals without mediators, and calprotectin was measured in the superna-

Table 1 Release of calprotectin from untreated buffy coats incubated for different times and at different temperatures with and without PMN from an equal volume of the same buffy coat

\begin{tabular}{lllllll}
\hline & $4^{\circ} \mathrm{C}$ & & & $37^{\circ} \mathrm{C}$ & \\
\cline { 2 - 3 } \cline { 5 - 6 } Sample & 24 hours & 1 hour & & 4 hours & 24 hours \\
\hline Buffy coat & $5.8 \mathrm{mg} / 1^{*}$ & $6.5 \mathrm{mg} / 1$ & & & $10.1 \mathrm{mg} / 1$ & $11.6 \mathrm{mg} / 1$ \\
Buffy coat and PBM & $10.2 \mathrm{mg} / 1^{*}$ & $13.9 \mathrm{mg} / 1$ & & $21.7 \mathrm{mg} / 1$ & $9.0 \mathrm{mg} / 1$ \\
\hline
\end{tabular}

The values are means of duplicates analysed in four dilutions.

$\star$ First incubated at $37^{\circ} \mathrm{C}$ for one hour. tants. Table 1 shows that a high concentration of calprotectin, which reached a plateau after four hours, was detected in buffy coat supernatants incubated at $37^{\circ} \mathrm{C}$. An additional 24 hour incubation at $4^{\circ} \mathrm{C}$ after an initial one hour incubation at $37^{\circ} \mathrm{C}$ did not influence the release of calprotectin. The release of calprotectin increased twofold when buffy coats were supplemented with PMN isolated from an equal volume of the same buffy coat, showing that PMN were responsible for the release and that the isolation of PMN per se was not a major background variable. In contrast to the finding with buffy coats alone, prolonged incubation of buffy coats plus PMN for 24 hours resulted in reduced calprotectin concentrations compared with the four hour value. This suggests that a time, temperature, and PMN dependent mechanism induced breakdown of calprotectin in the supernatants.

\section{Discussion}

Our results show that the endogenous $\mathrm{C} 5 \mathrm{a}$ and exogenous formyl peptide chemotaxins are taken up by PMN and promote in vitro release of calprotectin from PMN at or above the $\mathrm{ED}_{50}$ (median effective dose) of the ligands $(2-10 \mathrm{nM}) .^{33}{ }^{34}$ The indicated bimodal dose dependency curves (fig 3) for calprotectin release correspond with the reported bimodal curve for monocyte production of interleukin 8 (IL-8) after C5a stimulation, and might indicate a self-regulatory mechanism or desensitisation of the cells at high concentrations of the stimulator. ${ }^{1035}$ Our findings also indicate that the C5a and fMLP induced PMN secretion of calprotectin occurs via a $G$ protein coupled pathway, which is one proposed mechanism for the effects of C5a, fMLP, and other chemotactic ligands (IL-8, leukotriene B4) upon binding to their receptors in the rhodopsin receptor family. ${ }^{15}$ However, it has been suggested that a subpopulation of fMLP receptors on myeloid cells are maintained in a low affinity $G$ protein free state and are therefore pertussis insensitive. ${ }^{34}$ Because $\mathrm{C} 5 \mathrm{a}$ binds to a similar receptor to fMLP and has similar effects on PMN, C5a might also stimulate PMN via pertussis toxin sensitive and insensitive pathways. This might account for the incomplete inhibition in C5a and fLMP uptake and calprotectin release seen after peptide stimulation of pertussis toxin treated cells.

There was a high background release of calprotectin into the supernatant from unstimulated PMN. Because endotoxin is a known inducer of PMN enzyme release, ${ }^{36}$ and stimulates calprotectin secretion from monocytes (Lyberg et al, unpublished data), it might also induce release of calprotectin from PMN. The experiments were performed under sterile conditions and rigorous efforts were made to exclude endotoxin contamination. Endotoxin was not detected in random samples, indicating that factors other than endotoxin were responsible for the background release of calprotectin. Because PMN are fragile and easily stimulated in vitro, as shown by their tendency to aggregate, handling of the cells during isolation might trigger some calprotectin release, but 
efforts to stabilise the cells did not reduce the leakage. However, experiments with unstimulated buffy coats indicated that the incubation temperature of $37^{\circ} \mathrm{C}$ was the parameter responsible for most of the background release of calprotectin in vitro. We chose this temperature in our experiments because it has been useful in C5a stimulation studies previously. ${ }^{142}$ In contrast with calprotectin in buffy coats alone, the concentrations of calprotectin in buffy coats incubated with $\mathrm{PMN}$ overnight at $37^{\circ} \mathrm{C}$, but otherwise untreated, were reduced to the one hour value. Because there is a normal time and temperature dependent activation of complement in stored plasma, ${ }^{37}$ the observed calprotectin reduction is probably a result of $\mathrm{C} 5 \mathrm{a}$ formation and induction of PMN release of proteolytic enzymes, which might digest the secreted calprotectin.

Isolated calprotectin is digested by lysosomal enzymes from $\mathrm{PMN}$ at $37^{\circ} \mathrm{C}$ in the absence of enzyme inhibitors. ${ }^{26}$ Therefore, calprotectin is probably better protected intracellularly than extracellularly after release induced by $\mathrm{C} 5 \mathrm{a}$ and fMLP, which also mediate release of lysozymes. Because of the calprotectin degradation by proteolytic enzymes, we used the remaining cellular calprotectin concentration to estimate the amount of protein released after peptide stimulation. The determined PMN associated calprotectin in lysates, like the measured cell associated $\mathrm{C} 5 \mathrm{a}$ (fig 2), ${ }^{28}$ comprises both intracellular and membrane bound protein. Using the same polyclonal anti-L1 antibody that we used, Dale and colleagues ${ }^{3}$ demonstrated immunofluorescent staining of calprotectin both in the cytoplasm and on the plasma membrane of PMN along with lysozyme. Moreover, in activated monocytes, $\mathrm{L} 1$ subunits are shown to associate with the membrane and cytoskeleton in a $\mathrm{Ca}^{2+}$ dependent manner. ${ }^{38}$ In fact, the observed $10 \%$ minimal retention of total calprotectin in lysates of PMN stimulated with the most effective C5a and fMLP doses suggests that some calprotectin is located in the cell membranes during exocytosis of the protein.

In addition to proteolytic lysozymes, activated PMN release other antimicrobial factors like oxygen radicals and defensins. However, the importance of calprotectin release relative to other antimicrobials in vivo was demonstrated by Santhanagopalan and colleagues, ${ }^{39}$ who found calprotectin to be responsible for most of the anti-Candida albicans activity of empyema fluid supernatants. Previously, abscess fluid supernatants have been found to inhibit microbial growth, an effect that appeared to be a result of PMN cytoplasmic calprotectin. ${ }^{40}$ The fact that crude empyema fluid contains $25-50 \%$ PMN by volume ${ }^{39}$ suggests the importance of chemotaxins for PMN recruitment and subsequent calprotectin secretion. In septicaemia, another condition that induces C5a and fMLP formation, the plasma concentrations of calprotectin are reportedly over threefold higher than in healthy individuals. ${ }^{1}$ To estimate the proportion of the increase in in vivo calprotectin concentrations that C5a and fMLP might contribute to, one could compare our in vitro findings with the normal plasma concentration of calprotectin $(0.5 \mathrm{mg} / \mathrm{l})$ and adjust the figures for the 10 fold higher PMN concentration used in vitro. A brief calculation of the maximal net PMN calprotectin concentration released by $\mathrm{C} 5 \mathrm{a}$ and fMLP in vitro $(15 \%$ and $30 \%$ of total $10 \mu \mathrm{g} / 5 \times 10^{6} \mathrm{PMN}$ ) (fig 3 ) gives threefold and sixfold, respectively, higher calprotectin concentrations than is normally found in vivo.

During invasion with microorganisms, complement activation and subsequent C5a generation is one of the host's defense mechanisms. Because $\mathrm{C} 5 \mathrm{a}$ recruits $\mathrm{PMN}$ and monocytes to the infection focus and calprotectin is shown to possess antimicrobial activities, ${ }^{4-6}$ secretion of calprotectin from C5a stimulated PMN might be biologically useful. The dose response experiments show that the antimicrobial agent can be secreted from intact live PMN and not just released from dead and disintegrated cells. Formyl peptides are bacterial products. The proposed ability of fMLP to induce secretion of calprotectin from PMN supplements the role of $\mathrm{C} 5 \mathrm{a}$ during infection. Bacteria killed by calprotectin might release additional fMLP, which again would promote secretion of more calprotectin from a higher number of newly recruited PMN and thus give rise to a positive feedback loop. Bacterial endotoxin could induce a similar calprotectin driven antimicrobial effect that acts additively with the fMLP induced effect.

We thank Prof A Aasen, University of Oslo, for testing the content of endotoxin in our samples and Prof K Bergh, University of Trondheim, for monoclonal antibodies to $\mathrm{C} 5 \mathrm{a} / \mathrm{C} 5 \mathrm{a}$ desArg.

1 Fagerhol MK, Dale I, Andersson T. Release and quantitation of a leukocyte derived protein (L1). Scand $\mathcal{F}$ Haematol 1980;24:393-8

2 Dale I, Fagerhol MK, Naesgaard I. Purification and partial characterization of a highly immunogenic human leukocyte protein, the L1 antigen. Eur F Biochem 1983;143:1-6.

3 Dale I, Brandzaeg P, Fagerhol MK, et al. (1985) Distribution of a new myelomonocytic antigen (L1) in human peripheral blood leukocytes. Am f Clin Pathol 1985;84:2434 .

4 Steinbakk M, Næss-Andresen C-F, Lingaas E, et al. Antimicrobial actions of calcium binding leucocyte L1 protein, crobial actions of calcium binding lectin. Lancet 1990;336:763-5.

5 Sohnle PG, Collins-Lech C, Wiessner JH. The zincrehnle PG, Collins-Lech C, Wiessner JH. The zincabscess fluid supernatants. F Infect Dis 1991;164:137-42.

6 Miyasaki KT, Bodeau AL, Murthy JH, et al. In vitro antimicrobial activity of the human neutrophil cytosolic S-100 protein complex, calprotectin, against Capnocytophaga putigena. F Dental Res 1993;72:517-23.

7 Sander J, Fagerhol MK, Bakken JS, et al. Plasma levels of the leucocyte L1 protein in febrile conditions: relation to aetology, number of leucocytes in blood, blood sedimentation reaction and C-reactive protein. Scand $\mathcal{F}$ Clin Lab Invest 1984;44:357-62.

8 Berntzen HB, Fagerhol MK, Østensen M, et al. The L1 protein as a new indicator of inflammatory activity in patients with juvenile rheumatoid arthritis. I Rheumatol 1991;18: with ju.

9 Berntzen HB, Munthe E, Fagerhol MK. A longitudinal study of the leukocyte protein $\mathrm{L} 1$ as an indicator of disease activity in patients with rheumatoid arthritis. I Rheumatol 1989;16:1416-20.

10 Chenoweth DE, Hugli TE. Demonstration of a specific C5a receptor on intact human polymorphonuclear leukocytes. Proc Natl Acad Sci USA 1978;75:3943-7.

11 Haviland DL, McCoy RL, Whitehead WT, et al. Cellular expression of the $\mathrm{C} 5 \mathrm{a}$ anaphylatoxin receptor $(\mathrm{C} 5 \mathrm{aR})$ : demonstration of $\mathrm{C} 5 \mathrm{aR}$ on nonmyeloid cells of the liver and lung. F Immunol 1995;154:1861-9.

12 Gerard NP, Gerard C. The chemotactic receptor for human C5a anaphylatoxin. Nature 1991;349:614-17.

13 Niedel J, Wilkinson S, Cuatrecasas P. Receptor-mediated uptake and degradation of ${ }^{125}$ I-chemotactic peptide by
human neutrophils. $\mathcal{F}$ Biol Chem 1979;254:10700-6.

14 Sozzani S, Sallusto F, Luini W, et al. Migration of dendritic cells in response to formylpeptides, C5a, and a distinct set of chemokines. F Immunol 1995;155:3292-5. 
15 Feltner DE, Smith RH, Marasco WA. Characterization of the plasma membrane bound GTPase from rabbit neutrophils. I. Evidence for an Ni-like protein coupled to the formyl peptide, C5a, and leukotriene B4 chemotaxis receptory

16 Webster RO, Zanolari B, Henson PM. Neutrophil chemotaxis in response to surface-bound C5a. Exp Cell Res 1981 129:55-62

17 McPhail LC, Snyderman R. Activation of the respiratory burst enzyme in human polymorphonuclear leukocytes by chemoattractants and other soluble stimuli. Evidence that the same oxidase is activated by different transductional mechanisms. F Clin Invest 1983;72:192-200.

18 Becker EL, Showell HJ, Henson PM, et al. The ability of chemotactic factors to induce lysosomal enzyme release. I. The characteristics of the release, the importance of surfaces and the relation of enzyme release to chemotactic responsiveness. F Immunol 1974;112:2047-54.

19 Damerau BE, Grunefeld E, Vogt W. Aggregation of leukocytes induced by the complement-derived peptides C3a and C5a and by three completic formyl-methionyl pepC3a and C5a and by three synthetic formyl-methionyl

20 Hetland G, Berntzen HB, Fagerhol MK. Levels of calprotectin (leukocyte L1 protein) during apheresis. Scand 7 Clin Lab Invest 1992;52:479-82.

21 Hetland G, Mollnes TE, Garred P. Activation of complement during apheresis. Clin Exp Med 1991;84:535-8.

22 Garred P, Fosse E, Fagerhol MK, et al. Calprotectin and complement activation during major operations with or without cardiopulmonary bypass. Ann Thorac Surg 1993, 55:649-59.

23 Bøyum A. Isolation of mononuclear cells and granulocytes from human blood. Scand 7 Clin Lab Invest 1968;21 (suppl 97):77-89.

24 Hetland G, del Zoppo GJ, Mori E, et al. Uptake of C5a by polymorphonuclear leukocytes (PMNs) after focal cerebral ischemia. I. Effect of tirilazad mesylate intervention on C5a uptake by PMNs. Immunopharmacology 1994;27:191-8.

25 Røseth AG, Fagerhol MK, Aadland E, et al. Assessment of the neutrophil dominating protein calprotectin in faeces. A the neutrophil dominating protein calprotectin in faeces. A 8 .

26 Fagerhol MK. Nomenclature of proteins: is calprotectin a proper name for the elusive myelomonocytic protein? $\mathrm{f}$ Clin Pathol: Mol Pathol 1996;49:M74-9.

27 Brandtzaeg P, Jones DB, Flavell DJ, et al. Mac 387 antibody and detection of formalin resistant myelomonocytic $\mathrm{Li}$ antigen. F Clin Pathol 1988;41:963-70.
28 Bergh K, Iversen OJ. Production of monoclonal antibodies against the human anaphylatoxin C5a desArg and their application in the neoepitope-specific-sandwich-ELISA for
the quantification of C5a des Arg in plasma. F Immunol Methods 1992;152:79-87.

29 Hetland G, Moen O, Bergh K, et al. Both plasma- and eukocyte-associated C5a are essential for assessment of C5a generation in vivo. Ann Thorac Surg 1997;63:1076-80.

30 Day AR, Pinon D, Muthukumaraswamy N, et al. Synthesis of several chemotactic peptide antagonists. Peptides 1980;1: 289-91.

31 Levin J, Bang FB. The role of endotoxin in the extracellular coagulation of limulus blood. Bull fohn Hopkins Hosp 1964; 115:265-74.

32 Duff GW, Atkins E. The inhibitory effect of polymyxin B on endotoxin-induced endogenous pyrogen production. $\mathcal{F}$ Immunol Meth 1982;52:333-40.

33 Chenoweth DE, Goodman MG. The C5a receptor of neutrophils and macrophages. Agents Actions 1983;12(suppl): 252-73.

34 Prossnitz ER, Quehenberger O, Cochrane CG, et al. Signal transducing properties of N-formyl peptide receptor expressed in undifferentiated HL60 cells. F Immunol 1993; 151:5704-15.

35 Ember JA, Sanderson SD, Hugli TE, et al. Induction of interleukin-8 synthesis from monocytes by human C5a anaphylatoxin. Am $\mathcal{F}$ Pathol 1994;144:393-403.

36 Dahinden C, Galanos C, Fehr J. Granulocyte activation by endotoxin. I. Correlation between adherence and other granulocyte functions, and role of endotoxin structure on biologic activity. F Immunol 1983;130:857-62.

37 Mollnes TE, Garred P, Bergseth G. Effect of time, temperature and anticoagulants on in vitro complement activation: consequences for collection and preservation of samples to be examined for complement activation. Clin Exp Immunol 1988;73:484-8.

38 Burwinkel F, Roth J, Goebeler M, et al. Ultrastructural localization of the S-100-like proteins MRP8 and MRP14 in monocytes is calcium-dependent. Histochemistry 1994; 101:113-20.

39 Santhanagopalan V, Hahn BL, Dunn BE, et al. Antimicrobial activity of calprotectin isolated from human empyema fluid supernatants. Clin Immunol Immunopathol 1995;76: 285-90.

40 Sohnle P, Collins-Lech C, Wiessner JH. The zinc-reversible antimicrobial activity of neutrophil lysates and abscess fluid supernatants. F Infect Dis 1991;164:137-42. 